\title{
A Study of Environmental Policies and Regulations, Governance Structures and Environmental Performance: The Role of Female Directors
}

Mohamed H. Elmagrhi ${ }^{\mathrm{a}, \mathrm{a}} \bullet$, Collins G. Ntim ${ }^{\mathrm{b}}$, Ahmed Elamer $^{\mathrm{c}}$, and Qingjing Zhang ${ }^{\mathrm{b}}$

${ }^{a}$ Centre for Sustainability, Responsibility, Governance and Ethics (SURGE)

Department of Accountancy, Finance and Economics

Huddersfield Business School

University of Huddersfield Huddersfield, UK
${ }^{a 1}$ Department of Accounting and Finance Faculty of Economics and Commerce Al Asmarya University for Islamic Sciences Zliten, Libya

${ }^{\mathrm{b}}$ Centre for Research in Accounting, Accountability and Governance (CRAAG)

Department of Accounting Southampton Business School

University of Southampton

Southampton, UK

${ }^{\mathrm{c}}$ School of Management

Faculty of Management and Law

University of Bradford

Bradford, UK

\footnotetext{
- Corresponding author. Address for correspondence. Financial Ethics and Governance Research Group, Department of Accountancy, Finance and Economics, Huddersfield Business School, University of Huddersfield, Huddersfield, HD1 3DH, UK. Tel +44 (0) 1484 471529. E-mail: m.elmagrhi@ hud.ac.uk.
} 


\title{
A Study of Environmental Policies and Regulations, Governance Structures and Environmental Performance: The Role of Female Directors
}

\begin{abstract}
This paper seeks to contribute to the existing business strategy and the environment literature by examining the effect of governance structures on environmental performance within a unique context of improving environmental governance, policies, regulations and management. Specifically, we investigate the extent to which corporate board gender diversity, including the proportion, age and level of education of female directors, affect environmental performance of Chinese publicly listed corporations. Using one of the largest Chinese datasets to-date, consisting of a sample of 383 listed A-shares from 2011 to 2015 (i.e., observations of 1,674), our findings are three-fold. First, we find that the proportion and age of female directors have a positive effect on the overall corporate environmental performance. Second, our findings indicate that the proportion and age of female directors also have a positive effect on the three individual environmental performance components, namely environmental (i) strategy, (ii) implementation and (iii) disclosure, respectively. Finally, and by contrast, we do not find any evidence that suggests that the level of education of female directors has any impact on environmental performance, neither the overall environmental performance measure nor its individual components. Our findings have important implication for regulators and policy-makers. Our evidence is robust to controlling for alternative measures, other governance and firm-level control variables, and possible endogeneities. We interpret our findings within a multitheoretical framework that draws insights from agency, legitimacy, neo-institutional, resource dependence, stakeholder, and tokenism theoretical perspectives.
\end{abstract}

Keywords: Business strategy; environmental policies and regulations; environmental management and sustainable development; governance structures; environmental performance; corporate board gender diversity/female directors; China 


\section{Introduction}

China has achieved remarkable economic transformation and development over a relatively short period of time, primarily through massive production and manufacturing of goods and services (Du et al., 2014; McGuinness et al., 2017). Existing evidence suggests that such a rapid economic development has been achieved mainly at great environmental and social costs (Gao, 2009; Du, 2015). Recent years have, however, witnessed a number of positive efforts by Chinese authorities towards addressing existing challenges in the form of good environmental governance, policies, regulations and management (Glass et al., 2016; McGuinness et al., 2017; Shahab et al., 2018a, b). This, therefore, serves as a motivation for us to examine the effect of governance structures, as measured by corporate board gender diversity (female directors), on environmental performance among Chinese listed firms. Specifically, we depart from much of the existing literature that examines the mere presence of female directors on corporate performance by investigating the effect that unique female director characteristics, such as the proportion, age, and the level of education of female directors have on environmental performance using a sample of 383 listed A-shares in China over the 2011-2015 period. In this case, the current study focuses on the proportion, age, and the level of education of female directors because these characteristics are relatively easier to objectively observe and measure (Cummings, 2008; Hambrick \& Mason, 1984; Li et al., 2017), and prior non-Chinese studies suggest that these characteristics can have important impact on firm strategic decisions, including those relating to engaging in environmentally responsible practices/strategies (Ciocirlan \& Pettersson, 2012; Dollinger, 1984; Diamantopoulos et al., 2003). Our analysis is informed by a multitheoretical framework that draws insights from agency, legitimacy, neo-institutional, resource dependence, stakeholder, and tokenism theoretical perspectives.

Theoretically, the effect of board gender diversity/female directors on firms' environmental performance can be explained using a number of theories. First, agency theory suggests that board gender diversity/female directors can enhance board independence and effectiveness by increasing monitoring of the opportunistic behaviour of management (Jensen \& Meckling, 1976; Van Slyke, 2006), and this can result in improving corporate environmental performance. Second, from stakeholder and resource dependence theoretical perspectives (Haque \& Ntim, 2018; McGuinness et al., 2017), board gender diversity/female directors can increase pressure on firms to adopt different environmental practices in order to meet the expectation of stakeholders. Therefore, demonstrating commitments to greater accountability via adopting different environmental practices can help firms to obtain access to critical resources, by winning the support of powerful stakeholders (Branco \& Rodrigues, 2006; Erdiaw-Kwasie et al., 2017). Third, legitimacy and neo-institutional theories (Deegan, 2002; Scott, 2001; Soobaroyen \& Ntim, 2013; Shahab et al., 2018a, b) suggest that board gender diversity/female directors can improve firms' reputation and image by increasing their commitments to the environment and society in general. Finally, tokenism theory (Torchia et al., 2011) suggests that firms may appoint a small number of women/ethnic minorities simply to show sexual/racial equality within their boards, rather than to genuinely seek their views when making major decisions. Based on this view, tokenism theory expects that women and ethnic minorities' presence on corporate boards will have less influence on firms' environmental performance. In brief, while agency, stakeholder and resource dependence theories mainly focus on the economic benefits that can be obtained from improving gender diversity and environmental performance, legitimacy, 
neo-institutional and tokenism theories tend to be concerned with the wider public and social benefits of female board representation. However, given that the ability of each of the above theories to fully explain the effect of female directors on firms' environmental performance is limited, it is arguably necessary to use a multi-theoretical framework by adopting insights from each of these different theories. This can enhance their explanatory power by complementing each other in terms of their strengths and limitations.

Empirically, despite increasing suggestions that board diversity can have significant influence on firms' environmental performance (McGuinness et al., 2017), existing studies have mainly investigated the effect of board diversity on (i) firm financial performance (Erhardt et al., 2003; Carter et al., 2003, 2010); (ii) corporate governance disclosures (Al-Bassam et al., 2018; Elmagrhi et al., 2016, 2017, 2018; Sarhan \& Ntim, 2018a, b); and (iii) environmental and social disclosures (Barako \& Brown, 2008; Liao et al., 2015; Alnabsha et al., 2018). In contrast, studies investigating the impact of board diversity on firms' actual environmental performance are generally rare (Bear et al., 2010; Boulouta, 2013; Hafsi \& Turgut, 2013; Harjoto et al., 2015). More importantly, these few studies suffer from a number of limitations. First, such studies are impaired in that they have mainly been carried out in the developed countries, with relatively little attention paid to environmental performance in key emerging markets (e.g., Boulouta, 2013; Hafsi \& Turgut, 2013; Harjoto et al., 2015), and thereby arguably limiting the generalisability of their findings to developing contexts, such as that of China. China, for example, have different accounting, governance, financial, environmental regulations and cultural practices that can impact differently on environmental performance (Chen et al., 2017; Du et al., 2014; Shahab et al., 2018a, b). This, therefore, serves as a strong motivation for us to examine the impact of board diversity/female directors on environmental performance among Chinese listed firms.

Second, not only a few of these studies have focused on board gender diversity (Carter et al., 2003, 2010), but also they tend to examine the mere presence of female directors on corporate boards rather than how other equally important gender aspects, such as female directors' age, expertise and level of education, affect corporate outcomes, like environmental performance, and therefore, this offers a fertile area for further research. Third, prior studies conducted in China have measured firms' environmental performance by using either (i) dummy variables (e.g., Jia \& Zhang, 2011) or (ii) a composite measure from Rankins (RKS) (McGuinness et al., 2017; Lau et al., 2016; Liao et al., 2016; Shahab et al., 2018a, b). These summary environmental performance measures are unable to accurately capture the nuanced nature of both the length (scale) and breadth (depth) of environmental activities in China (Shahab et al., 2018a, b), and therefore, this raises some level of doubt regarding the generalisability of the findings of past Chines studies. Thus and in this study, we depart from existing Chinese studies by employing a comprehensive measure of environmental performance that takes into account three categories of the $R K S$ ratings, namely: (i) macrocosm; (ii) content; and (iii) technique. The first category of RKS ratings (macrocosm) assesses the overall corporate environmental strategy. The second category (content) assesses the effectiveness of the implemented environmental strategy, and the final category (technique) assesses the extent of environmental reporting.

Fourth, despite increasing suggestions that the implementation of good environmental practices requires firms to devote their financial and non-financial resources over a long period of time to 
achieve long-term positive effects (Boulouta, 2013; Harjoto et al., 2015), most of the prior studies that examine Chinese firms' environmental performance have been conducted over a short period of time (with exception of McGuinness et al., 2017), and this, arguably, limits our understanding of the extent to which board diversity can impact on firm's environmental performance over a long-period of time. Therefore, the current study seeks to contribute to the literature by investigating the impact of board diversity on firm environmental performance over a long period of time, covering 2011 to 2015 period. Finally, despite increasing empirical and theoretical evidence that using a multitheoretical framework can provide better explanation of issues relating to firms' environmental performance (Haque \& Ntim, 2018), prior studies have been either descriptive in nature (Gao, 2009) or employed single theoretical perspective (McGuinness et al., 2017; Jia \& Zhang, 2011; Lau et al., 2016). This arguably impairs current ability to understand and explain the impact of board diversity on firm's environmental performance. Thus, this serves as a strong motivation for us to employ a multi-theoretical framework that uniquely draws insights from agency, legitimacy, neo-institutional, resource dependence, stakeholder, and tokenism theoretical perspectives.

We focus on China because it has made a huge economic transformation and development through massive manufacturing and production in the last few decades, and this has mostly been pursued at the expense of the environment and society (Xu et al., 2018; Shahab et al., 2018a, b). This neglect led to the creation of serious environmental and social problems, such as poor air, water and soil quality and pollution, as well as persistent smog, which has had negative health effects on people (Du, 2015; McGuinness et al., 2017). However, since late 1990s, and in response to increasing environmental and social problems, different national and international governance and environmental laws, polices, regulations and standards have been adopted in China (e.g., Corporate Governance Codes, Company Law, Labour Law, OECD Gender Initiative guideline; Environmental Protection Law, Paris Agreement on Climate Change, and Global Reporting Initiative standards) (e.g., Adema et al., 2014; McGuinness et al., 2017; Du, 2015; Tang et al., 2018; Shahab et al., 2018a, b). Additionally, Shanghai and Shenzhen stock exchanges have issued several governance codes and regulations aimed at enhancing environmental and social disclosures among listed firms (Weber, 2014; Carter \& Mol, 2013). However, despite the adoption of these different rules, governance codes, regulations and laws, the environmental and social problems are still prevalent in China, and this is arguably mainly due to the weak law enforcement and limited role played by these codes of ethics in encouraging environmentally and socially friendly activities (Du et al., 2014; Du, 2015). One way to increase firms' commitment towards resolving environmental and social problems is by appointing more women from a wide range of educational backgrounds to corporate boards (Bear et al., 2010; Harjoto et al., 2015; McGuinness et al., 2017). However, despite the importance of board diversity in promoting environmentally and socially friendly behaviours, there has not been much research examining the impact of board gender diversity, in terms of the proportion, age and educational level of female directors, on Chinese firms' environmental performance, and this makes it a ripe area for further research. Therefore, the current study aims to answer the following research question - to what extent can board gender diversity in the form of female directors (i.e., in terms of the proportion, age and level of education of female directors) impact on Chinese firms' environment performance?

Our results that answer the above question are three-fold. First, our results suggest that the proportion and age of female directors have a positive and significant impact on the overall corporate environmental performance. Second, we find that the proportion and age of female directors also have 
a positive and significant effect on the three individual components of environmental performance, namely environmental (i) strategy, (ii) implementation and (iii) disclosure, respectively. Finally, our findings indicate that neither the level of education of female directors has any influence on the overall corporate environmental performance nor its individual components. Our study, therefore, extends, as well as contributes to the extant literature in a number of ways. First, we contribute to the limited studies in China by examining the effect of board gender diversity/female directors on firm's environmental performance. We do this specifically by employing a comprehensive measure of environmental performance that takes into account the three categories of the RKS ratings (i.e., macrocosm, content and technique). Second, we contribute to the limited literature by using a large dataset on corporate governance, board gender diversity/female directors and firm's environmental performance from 2011 to 2015 (i.e., the total number of observations is 1,674). Additionally, unlike most of prior Chinese studies (Gao, 2009; Jia \& Zhang, 2011; Lau et al., 2016), which tended to focus solely on the most polluting industries, we include a diverse range of industries in our study and examine their environmental performance. Third, we contribute to the limited extant literature by employing a multi-theoretical framework to explain the impact of board diversity/female directors on firm's environmental performance. We argue that the ability of any single theory to fully explain the effect of board gender diversity/female directors on firm's environmental performance is likely to be significantly impaired, and therefore provides a compelling justification for the use a multi-theoretical framework that incorporates insights from agency, stakeholder, resource dependence, legitimacy, neo-intuitional and tokenism theoretical perspectives.

The remainder of the paper is structured as follows. The next section will briefly discuss economic, environmental and governance issues in China. The following sections will present the underlying theories, review empirical literature and hypotheses development, outline the research design, and report the findings, whilst the final section will provide concluding remarks.

\section{Environmental Regulations, Governance Structures and Social Reforms in China}

China has achieved remarkable economic growth over the last few decades and is now the world's largest manufacturing economy (Du, 2015; Shahab et al., 2018a, b). Indeed, China has not only become one of the world's most competitive manufacturing nation, but also is today the world's second largest economy and, likely to become the largest economy in the world in the next few years (Du et al., 2014). However, this rapid economic transformation has been achieved at the expense of the environment and society (McGuinness et al., 2017). Specifically, in the past, the Chinese government and corporations focused mainly on economic growth through massive manufacturing and production and ignored environmental and social policies and regulations. Consequently, China's emergence, as a leading world economy, was achieved at the expense of damaging the environment and society. For example, China is today the world's largest energy consumer, with coal energy accounting for about $70 \%$ of her total energy consumption (He, 2015; Jiao et al., 2018). As a result of this, China is considered as the world's largest carbon-dioxide polluter. Similarly, according to the World Health Organisation (WHO) report in 2014, excessive air pollution is the major environmental cause of death in China (WHO, 2014). Therefore, although China has become economically advanced, this has observably been achieved by compromising on the environment and societal health. 
In response to these serious environmental and social consequences (e.g., poor health conditions resulting from high carbon-dioxide emissions, air, water and soil pollution and hazardous wastes), the Chinese government and other regulatory bodies have recently introduced several environmental laws and regulations. Specifically, in 1989, the Chinese government issued the first Environmental Protection Law (revised in 2014), which aimed at improving environmental performance among firms in China (Carter \& Mol, 2013). Additionally, since 2001, firms are required to disclose information about their environmental risks in order for them to be listed on the Shenzhen and Shanghai Stock Exchanges (Weber, 2014). Similarly, in 2001 (revised in 2004), the first corporate governance code was issued by the China Securities Regulatory Commission. It required Chinese firms, especially listed ones to commit not only to good governance practices, such as ensuring board diversity (e.g., age, experience, gender and expertise), independence (e.g., ensuring CEO role duality and having a majority of non-executive directors) and disclosure (e.g., greater financial and non-financial disclosures), but also to good environmental practices. Furthermore, to promote the environmental performance of the Chinese listed firms, both Shenzhen and Shanghai Stock Exchanges also introduced additional guidelines on voluntary environmental and social performance disclosures in 2006 and 2007, respectively. These guidelines required the listed firms to publish separate corporate social responsibility and environmental reports that will outline their environmental and social performance (Noronha et al., 2013).

Further, the Chinese company law of 2006 requires firms to embed environmental and social responsibility into their activities. For example, article 18 of the company law requires firms to consult with their employees and trade unions when making significant operational decisions that may affect employees' wages, welfare, as well as other issues related to the interests of employees. Similarly, in December 2011, the State-Owned Assets Supervision and Administration Commission of the State Council (SASAC) introduced a guideline, which cover most of the international corporate environmental and social responsibility standards. The guideline aimed at promoting high standards of corporate environmental and social responsibility by enhancing accountability and transparency among the state-owned enterprises (Weber, 2014). Additionally, in December 2016, the Chinese National People's Congress (NPC) Standing Committee approved the Environmental Protection Tax Law. This law came into operation from January 2018 and aims to impose tax on the industrial emissions and pollution. In addition to the national environmental and social responsibility guidelines and standards, China has also been influenced by international sustainability guidelines and agreements. For example, according to Weber (2014), many Chinese firms have followed the Global Reporting Initiatives (GRI) guidelines when disclosing information relating to their sustainability performance. Similarly, in September 2016, China joined Paris Agreement on Climate Change, and since then has increasingly become a major partner in the global fight against climate change and global warming. For example, China has agreed to include climate change in its socio-economic development programmes by reducing carbon emissions to sustainable levels (Gao, 2016).

However, despite the recent development of different measures to improve firms' environmental performance, the implementation of these environmental regulations, polices and laws is fairly poor, and this is mainly due to the weak law enforcement (Du et al., 2014; Du, 2015). One way to improve the implementation of environmental regulations is to strengthen corporate governance structures, and particularly by appointing more women and independent directors from a wide range of educational backgrounds to corporate boards (Bear et al., 2010; Harjoto et al., 2015; McGuinness et 
al., 2017; Nasr \& Ntim, 2018). From a regulatory perspective, although there is no national legal requirement for firms listed on the Chinese Stock Exchanges to have diverse boards, the Chinese corporate governance codes (e.g., 2001, 2004) recommend that firms should aspire to achieve diversity, especially gender diversity on their boards. Similarly, due to the influence of international organisations, such as OECD, corporate boards of Chinese firms are now steadily becoming diverse through the appointment of more minorities in the form of female directors (Grant Thornton Report, 2018). We, therefore, seek to examine the unique settings of board gender diversity/female directors (i.e., gender, age and educational background) and their impact on the Chinese firms' environmental performance.

\section{Theoretical Framework}

Despite growing calls for studies to adopt multi-theoretical framework in explaining issues relating to environmental performance, prior studies have been either descriptive in nature or mainly employed a single theoretical perspective (Gao, 2009; McGuinness et al., 2017; Jia \& Zhang, 2011). There is only one study, which was conducted by Lau et al. (2016) that used agency, resource dependence and institutional theoretical perspectives to explain the impact of governance structures (i.e., ratios of non-executive directors, directors' experience, ratio of state ownership and top management team educational background and work experience) on corporate social responsibility performance. Given that there is no one theoretical framework that can fully explain the effect of board gender diversity on firms' environmental performance, and in response to the recent increasing calls for theoretical integration (Haque \& Ntim, 2018; Lau et al., 2016; Shahab et al., 2018a, b), we address the limitations of prior studies by adopting a multi-theoretical framework. Specifically, our analysis is informed by theoretical insights drawn from agency, stakeholder, resource dependence, legitimacy, neo-intuitional and tokenism theoretical perspectives.

Briefly and according to agency theory (Jensen \& Meckling, 1976; Nasr \& Ntim, 2018), agents (managers) are often self-motivated and they mainly focus on maximising their own benefits at the expense of principals (shareholders). In this case, board gender diversity/female directors can be a useful way in reducing agency and information asymmetry problems by increasing board effectiveness (McGuinness et al., 2017), and that may improve firm environmental performance. However, the importance of agency theory in explaining the effect of board diversity/female directors on firms' environmental performance is limited because it tends to assume that agents (managers) mainly focus on maximising their financial benefits, but this is not always true, as managers are often motivated (at least partially) to act in the best interest of shareholders (Van Slyke, 2006).

Also, stakeholder and resource dependence theoretical perspectives view board gender diversity/female director representation as a good mechanism by which firms can manage the needs of their various influential stakeholders in order to access critical resources (Freeman \& Reed, 1983; Pfeffer \& Salancik, 1978; Elamer et al., 2018). Specifically, stakeholder theory suggests that there is a contractual relationship between managers and stakeholders, whereby managers are committed to represent and meet the expectations of stakeholders in order to obtain their approval (Erdiaw-Kwasie et al., 2017; Haque \& Ntim, 2018). Similarly, resource dependence theory indicates that board of directors seek to connect firms to critical resources by providing better networks with powerful stakeholders (Branco \& Rodrigues, 2006; Ntim, 2016). In this setting, board gender diversity/female 
directors can increase the presentation of stakeholders by bringing different ideas, skills and perspectives to corporate board decision-making (McGuinness et al., 2017). Consequently, that may increase the pressure on managers to improve firm environmental performance in order to satisfy powerful stakeholders, and thus secure access to critical resources. However, notwithstanding their potential usefulness in explaining the effect of board gender diversity/female directors on firms' environmental performance (McGuinness et al., 2017), stakeholder and resource dependence theories are impaired in that they mainly focus on satisfying the needs of powerful stakeholders, who may often be financial stakeholders, rather than non-financial stakeholders (e.g., the broader environment and society) (Reverte, 2009).

Finally, legitimacy, tokenism and neo-institutional theories tend to focus on how board gender diversity/female directors and environmental performance may be used to obtain approval from the wider society, which may enable firms to survive and be successful (Bear et al., 2010; Haque \& Ntim, 2018; Torchia et al., 2011). Specifically, legitimacy theory suggests that an organisation can legitimise its activities by ensuring that its value systems is congruent with the value system of the broader society; however, the legitimacy of an organisation may threatened when a potential/actual conflict exists between the two value systems (Deegan, 2002). Similarly, tokenism and neoinstitutional theories indicate that organisations can legitimise their operations by inculcating external norms, regulations and practices into their operations, processes and procedures (Scott, 2001; Shahab et al., 2018a, b; Torchia et al., 2011). Therefore, it can be argued that firms can attain social legitimacy and acceptance by appointing more women into their boards, which can improve their environmental performance. However, notwithstanding their relevance in providing an understanding of the effect of board gender diversity/female directors on environmental performance (Torchia et al., 2011; McGuinness et al., 2017), the three theories are impaired by a number of limitations, including lack of clarity and specificity about the identity of stakeholders, as well as offering priority to financial stakeholders (Ntim \& Soobaroyen, 2013a, b; Zimmer, 1988; Sarhan \& Ntim, 2018a, b).

As each of the above theories is limited to some extent in explaining the effect of board diversity/female directors on environmental performance, we interpret the findings from a multiple theoretical perspective.

\section{Past Empirical Studies and Hypotheses Development}

\section{Board gender diversity and environmental performance}

From agency theoretical perspective, board gender diversity/female directors can play an important role in improving board effectiveness, including increasing managers' commitments towards environment and society in general, by increasing managerial monitoring, as well as bringing a diverse range of ideas, views, perspectives and skills to a corporate board (McGuinness et al., 2017). Similarly, stakeholder and resource dependence theories suggest that having more females on a corporate board can increase pressure on firms to demonstrate higher environmental performance in order to obtain the support of powerful stakeholders to secure access to critical resources (Branco \& Rodrigues, 2006; Haque \& Ntim, 2018). In addition, legitimacy and neo-institutional theories indicates that increasing the number of female directors can improve firms' reputation/image by strengthening corporate environmental responsibilities (Bernardi et al., 2009; Deegan, 2002; Scott, 2001; Shahab et al., 2018a, b). Finally, tokenism theory suggests that firms may appoint few female 
directors mainly for symbolic reasons (obtain legitimacy) rather than seeking their views when making strategic decisions regarding the environment (Torchia et al., 2011). Therefore, tokenism theory expects that female directors will have no significant influence on firms' environmental performance.

Empirically, the evidence relating to the effect of board gender diversity/female directors on firm environmental performance is generally limited, and most of the prior studies have mainly been carried out in developed countries, and therefore, offers a fertile opportunity to make original contribution to the literature. For example, and in line with the findings of prior studies (Bear et al., 2010; Bernardi et al., 2009; Boulouta, 2013; Hafsi \& Turgut, 2013), Williams (2003) and Zhang et al. (2013) report that board gender diversity/female directors significantly affect US firms environmental performance. In China, McGuinness et al. (2017) report that the higher the proportion of female directors, the stronger the corporate environmental performance. Therefore, we propose the following hypothesis:

Hypothesis 1. Board gender diversity is positively and significantly associated with firm's environmental performance in China.

To further investigate the impact of board gender diversity/female directors on firms' different environmental aspects, we distinctively develop the following sub-hypotheses based on the $R K S$ 's three aspects of measuring environmental performance (i.e., i. environmental strategies; ii. implementation of environmental strategies; and iii. environmental information disclosure).

Prior studies (e.g., Ciocirlan \& Pettersson, 2012; Bear et al., 2010; Pucheta-Martínez \& Bel-Oms, 2018; Williams, 2003) suggest that firms with female directors/gender-diverse boards tend to pursue environmentally responsible practices/strategies. For example, Glass et al. (2016) and Ciocirlan and Pettersson (2012) find that US firms with high proportions of female directors on board are associated with greater environmental performance than male-dominated boards. Similarly, Jia and Zhang $(2011,2013)$ argue that Chinese female directors have the ability to influence business strategies and decisions, particularly those relating to environmental activities. Based on the above arguments, we expect that female directors/board gender diversity can impact positively on firms' environmental strategies. Hence, our next hypothesis to be tested is that:

Hypothesis 1a. Board gender diversity is positively and significantly associated with firm's environmental strategies in China.

Board gender diversity/female directors can also play an important role in influencing the implementation of strong environmental related polices (Bernardi et al., 2009; Ibrahim et al., 2009). Jizi (2017) argues that board gender diversity/female directors can improve engagement with powerful stakeholders by bringing different skills, knowledge and expertise to a corporate board, and that can in turn facilitate the implementation of corporate environmental strategies. Empirically, Bernardi et al. (2009) and Boulouta (2013) find that female directors have a significant influence on corporate social responsibility issues among US firms. Consequently, we expect that female 
directors/board gender diversity might positively influence corporate environmental fulfilment. Therefore, we set forth the following hypothesis:

Hypothesis 1b. Board gender diversity is positively and significantly associated with firm's implementation of environmentally friendly activities in China.

Further, board gender diversity is argued to increase the involvement in environmental activities and disclosures (Liao et al., 2015; Jizi, 2017). Gul et al. (2011) and Jizi (2017) also consider board gender diversity as an important mechanism that enhances monitoring of management activities and facilitates disclosure on issues relating to environmental activities. Empirically, Ben-Amar et al. (2017), Boulouta (2013) and Liao et al. (2015) report a positive and significant association between board gender diversity and environmental disclosure among Canadian, US and UK firms, respectively. Based on the above arguments, we expect that female directors/board gender diversity might enhance disclosures about environmentally friendly activities. Thus, we develop the following hypothesis:

Hypothesis 1c. Board gender diversity is positively and significantly associated with firm's disclosures relating to environmental activities in China.

\section{Age of female directors and environmental performance}

Theoretically, age diversity is considered as an important factor that may explain part of the difference in environmental moral judgements among directors. Specifically, agency theory suggests that the environmental knowledge of directors continuously develops over time, and hence, older directors often tend to have a higher level of environmental moral reasoning compared with younger counterparts (Post et al., 2011). In this setting, agency theory expects that firms with older female directors tend to have better environmental performance than boards with younger directors. In contrast, legitimacy, stakeholder and resource dependence theories suggest that younger directors are more concerned about environmental problems and are motivated to support corporate reforms that aim to improve environmental quality (Hafsi \& Turgut, 2013; Ibrahim et al., 2016; Liere \& Dunlap, 1980). This may be due to the fact that they are willing to improve their current and future reputation in the labour market and gain the support of key stakeholders in order to gain access to critical resources. In this case, stakeholder, legitimacy and resource dependence theories expect young female directors to promote environmentally friendly activities.

Empirically, there is a lack of studies examining the influence of female directors' age on firms' environmental performance, and thus this offers a good opportunity to contribute to the existing research. Post et al. (2011) examined the association between directors' age and US firms' environmental performance and found positive link between them. However, Hafsi and Turgut (2013) report negative association between age diversity and firms' social performance. Given that prior studies found age diversity to have influence on firms' environmental performance, we hypothesise that:

Hypothesis 2. Age of female directors is positively and significantly associated with firms' environmental performance in China. 
In addition to examining the impact of age diversity on firm's overall environmental performance score, we distinctively develop the following sub-hypotheses based on the $R K S$ 's three environmental ((i) strategy, (ii) implementation and (iii) disclosure)) aspects of measuring environmental performance.

Age of directors is argued to have significant influence on firm's strategy towards the environment and society. Specifically, Ferrell et al. (2017) argue that older managers tend to have greater experience and knowledge to deal with complex ethical issues, and that in turn can positively influence firms' policies towards the environment and society. However, Hambrick and Mason (1984) and Vroom and Pahl (1971) argue that many cognitive abilities of managers (e.g., ability to make good and quick decisions, confidence in decisions) decline with age, and as a result, older managers often tend to avoid taking risks. This consequently may have significant effect on firm's strategic decisions, including those relating to the environment and society. Similarly, Cummings (2008) and Liere and Dunlap (1980) argue that younger managers often tend to accept and support reforms that are aimed at improving firms' environmental performance. Based on the above arguments, we expect that the age of female directors to be related to firm's strategy toward the environment, and hence we hypothesise that:

Hypothesis 2a. Age of female directors is positively and significantly associated with firm's environmental strategies in China.

Age of directors may also play an important role in influencing the implementation of strong environmental related strategies. Diamantopoulos et al. (2003) argue that old managers often have the financial ability and resources to support the implementation of strong environmental related policies. However, Hafsi and Turgut (2013) suggest that young managers often have more alertness and energy to deal with environmental and ethical issues, and hence that may strengthen the implementation of good environmental practices. Therefore, we argue that the age of female directors is likely to influence corporate environmental fulfilment. Thus, we hypothesise that:

Hypothesis 2b. Age of female directors is positively and significantly associated with firm's implementation of environmentally friendly activities in China.

Directors' age is also argued to influence the level of disclosure on issues relating to the environment and society (Cucari et al., 2018; Ibrahim et al., 2016). Ibrahim et al. (2016) argue that younger managers are more dynamic, innovative and open in terms of making changes to their firms' business strategies if necessary. Similarly, Vroom and Pahl (1971) suggest that younger managers tend to have less experience and prefer to take more risks in order to improve their status in the labour markets. This implies that younger managers are more likely to be motivated to engage in voluntary disclosure about environmental issues in order to improve their reputation/image in the labour market. Thus, we hypothesise that:

Hypothesis 2c. Age of female directors is positively and significantly associated with firm's disclosures relating to environmental activities in China. 


\section{Level of education of female directors and environmental performance}

Hitt and Tyler (1991) argue that the level of education can affect managers' cognitive ability and value system, and that may in turn influence firm's strategic decisions. Similarly, Hambrick and Mason (1984) suggest that managers' level of education can affect firm's degree of innovativeness, and hence firm's strategic decisions. Additionally, Diamantopoulos et al. (2003) indicate that more educated managers may put more pressure on their firms in order to control environmental issues, because they tend to have greater environmental awareness than less educated managers.

Empirically, existing studies investigating the impact of female directors' level of education on firm's environmental performance are rare, and therefore, offers a fertile opportunity to make original contributions to the literature. For example, Gadenne et al. (2009) report insignificant association between the level of education and managers' environmental behaviour and awareness. In contrast to this finding, and in line with the assumption of resource dependence theory, we expect more educated female directors to have better environmental awareness than less educated female directors, and hence, we propose the following hypothesis:

Hypothesis 3. Level of education of female directors is positively and significantly associated with firms' environmental performance in China.

In addition to examining the impact of female directors' educational level on firm's overall environmental performance score, we distinctively develop the following sub-hypotheses based on the $R K S$ 's three aspects of measuring environmental performance.

Female directors' level of education can affect firm's strategy towards environment and society by improving board independence and providing different perspectives of supervision (Hambrick \& Mason, 1984; Hitt \& Tyler, 1991; Zalata et al., 2018). Dollinger (1984) suggests that educated managers are more concerned about the external environment and they tend to be better able to deal with complex ethical issues, and that in turn can positively influence their firms' policies towards the environment and society. Empirically, Norburn and Birley (1988) report a positive association between changes in the business strategy and level of educations among US firms. Therefore, we expect that female directors' level of education can impact positively on firms' environmental strategies. Hence, our next hypothesis to be tested is that:

Hypothesis 3a. Level of education of female directors is positively and significantly associated with firm's environmental strategies in China.

Managers' level of education and knowledge can also influence the implementation of environmental management practices (Abdul Wahab et al., 2018). Gadenne et al. (2009) argue that educated directors tend to have more knowledge and experience about environment, and hence, they care more about ethical and environmental issues. Diamantopoulos et al. (2003) also suggest that educated directors are more motivated to support environmentally friendly activities in order to meet the expectations of stakeholders and obtain their approval. Therefore, we argue that female directors' 
level of education is likely to affect the level of corporate environmental fulfilment. Thus, we hypothesise that:

Hypothesis 3b. Level of education of female directors is positively and significantly associated with firm's implementation of environmentally friendly activities in China.

Finally, directors' educational level can also affect disclosure practices about environmental issues. Dollinger (1984), and Hambrick and Mason (1984) argue that educated directors are more likely to support innovative ideas and tolerate ambiguity. Additionally, Wallace and Cooke (1990) suggest that the demand for corporate accountability increases with the increase in the level of education of directors. Similarly, Haniffa and Cooke (2002) indicate that educated directors are more motivated to engage in voluntary disclosure practices in order to demonstrate public accountability and improve their firms' reputation/image. Therefore, we expect that the level of education of female directors might enhance disclosures about environmentally friendly activities. Thus, we develop the following hypothesis:

Hypothesis 3c. Level of education of female directors is positively and significantly associated with firm's disclosures relating to environmental activities in China.

\section{Research Design}

\section{Data and sample}

Our sample is drawn from all A-share listed companies on Shanghai Stock Exchange. We restricted our final sample to companies with full data available on Rankins Ratings $(R K S)$, and this resulted in having 269 companies in 2011, 313 in 2012, 344 in 2013, 365 in 2014 and 383 in 2015 (i.e., 1,674 firm-year observations). We started our study in 2011 because data on the number of female directors, age of female directors and level of education of female directors was not available before 2011. The financial year of 2015 was the last year for which data was available at the time of collecting the data. The Chinese Stock Market and Accounting Research (CSMAR) database was used to collect the data on board diversity/female directors, other governance measures and the control variables.

\section{Variable definition and econometric model}

Table 1 summarises all the main types of variables used in conducting our empirical analyses. To test our hypotheses, we use three main types of variables. First, the main dependent variable of this study is environmental performance. Following prior Chinese studies (Lau et al., 2016; McGuinness et al., 2017; Shahab et al., 2018a, b), we used ratings from Rankins $(R K S)$ as a proxy for environmental performance. Additionally, we distinctively include the three categories of the $R K S$ ratings, which are (i) macrocosm, (ii) content, and (iii) technique, to measure: (i) the overall corporate environmental strategy; (ii) the implementation of environmental strategies; and (iii) the extent of environmental disclosure, respectively.

Table 1 about here 
Second, our main independent variables are: percentage $(B G N)$, age $(A F D)$ and level of education $(L E F D)$ of female directors. Finally, to limit possible omitted variables bias (Gujarati, 2003), we include board size $(B R D Z)$, firm size $(F R M Z)$, leverage $(L V R G)$, profitability $(R O E)$ and stateownership $(S O W N)$, as control variables. Therefore, our estimated Ordinary Least Square (OLS) regression model is as follows:

$$
E S P R_{i t}=\alpha_{0}+\beta_{1} B G N+\beta_{2} A F D+\beta_{3} L E F D_{i t}+\sum_{l=1}^{5} \beta_{l} C T R S_{i t}+\varepsilon_{i t}
$$

Where ESPR represents our main dependent variables and are measured using corporate total environmental rating (TESPR), macrocosm $(M C R)$, content $(C N T)$ and technique $(T C H)$ scores. $B G N$, $A F D$ and $L E F D$ are our main independence variables and they refer to percentage, age and level of education of female directors, respectively. CTRS refers to firm-level control variables, including board size $(B R D Z)$, firm size (FRMZ), leverage ( $L V R G)$, profitability ( $R O E)$ and state-ownership $(S O W N)$. The empirical analyses of this paper, including descriptive statistics and multivariate regression are presented in the next sections.

\section{Empirical Results and Discussion}

\section{Descriptive statistics}

Summary descriptive statistics relating to the environmental performance score, board diversity/female directors and control variables have been presented in Tables 2 and 3, respectively. A number of interesting findings emerge from these tables. First, the evidence from Table 2 indicates that the environmental performance scores vary substantially among our sample. For example, TESPR ranges from a minimum of $12.53 \%$ to a maximum of $87.95 \%$ with a mean (a median) of $38.43 \%$ (35.12\%), which is similar to the finding of McGuinness et al. (2017). Similarly, the distribution of $M C R, C N T$ and $T C H$ scores shows similar pattern. MCR score, for example, ranges from a minimum of $2.81 \%$ to a maximum of $27.56 \%$, with a mean (a median) of $12.81 \%$ (11.95\%). Additionally, Table 2 shows that the environmental performance scores have increased over time. For example, the TESPR score has increased from 34.06\% in 2011 to $42.26 \%$ in 2015, accounting for about 24 percentage points increase over the five years investigated. Similarly, Table 2 shows that the scores of RKS three categories increase over time. For instance, Panel 2 and 3 of Table 2 suggest that $M C R$ and $C N T$ scores are increasing steadily from $10.47 \%$ (15.57\%) in 2011 to $14.76 \%(18.23 \%)$ in 2015 , accounting for about $41(17 \%)$ percentage points increase over the five years analysed.

Table 2 near here

Further, Panels 1, 2 and 3 of Table 3 present summary descriptive statistics relating to board diversity/female directors, corporate governance and general firm characteristics variables, respectively. Overall, the three panels show wide spread for all variables under examination. For example, and in line with the findings of prior studies (McGuinness et al., 2017), board gender diversity $(B G N)$ ranges from a minimum of $0 \%$ to a maximum of $55.56 \%$, with an average of $10.44 \%$, 
indicating that, on average, the board of Chinese A-listed firms are dominated by males. Age of female directors $(A F D)$ also ranges between 30 and 73 years with a mean value of 51 years. With reference to the other remaining variables, including the level of education of female directors $(L E F D)$ and control variables (BRDZ, SOWN, FRMZ, LVRG and ROE), all show wide variation, indicating that there is adequate variation in our variables.

Table 3 near here

Table 4 contains correlation matrix for all variables included in our study, in order to identify the presence of any multicollinearity problems. Overall, the levels of correlation among all variables are somewhat low, implying that there are no serious multicollinearity problems.

Table 4 near here

\section{Regression analyses and discussion}

Table 5 reports the results of the impact of board diversity/female directors (i.e., gender, age and level of education of female directors) on firms' environmental performance. Specifically, Model 1 reports the results of our main three hypotheses regarding the impact of female directors/board diversity of firms' overall environmental performance (TESPR), whereas Models 2, 3 and 4 show the results of our sub-hypotheses regarding the influence of board diversity on each dimension of the Rankins' $R K S$ ratings $(M C R, C N T$ and $T C H)$.

First, the proportion of female directors $(B G N)$ in Table 5 is positively and significantly associated with TESPR in Models 1, implying that hypothesis 1 is empirically supported. The positive effect of BGN on TESPR is also consistent with the findings of prior studies (Boulouta, 2013; Hafsi $\&$ Turgut, 2013; McGuinness et al., 2017) and the theoretical predictions that board gender diversity can play an important role in enhancing board effectiveness by bringing diverse perspective, knowledge, experience and ideas to the board (McGuinness et al., 2017). Our findings further extend the work of extant literature by validating that $B G N$ is positively and significantly associated with the adoption $(M C R)$ and implementation $(C N T)$ of good environmental strategies $(M C R)$, as well as disclosure about those strategies $(\mathrm{TCH})$.

Table 5 near here

Second, the findings reported by Model 1 of Table 5 suggest that there is a positive and significant association between the age of female directors $(A F D)$ and TESPR, and thus, hypothesis 2 is supported. This also provides empirical support for the predictions of agency theory that firms with older directors tend to have better environmental performance, and this may due to the fact that older managers often tend to have greater experience and knowledge to deal with complex ethical issues (Ferrell et al., 2017). Further, our findings extend the work of prior studies by indicating that age of female directors is positively and significantly associated with $M C R, C N T$ and $T C H$, in Models 2, 3 and 4, respectively. The implication of this finding is that old female directors tend to support the implementation of, and disclosure about, good environmental strategies in order to demonstrate public accountability and improve their firms' reputation/image (Diamantopoulos et al., 2003). 
Finally, the coefficient on the level of education of female directors ( $L E F D)$ in Model 1 of Table 5 is positively, but insignificantly associated with TESPR, implying that hypothesis 3 is not supported. The evidence does not also provide support for the predictions of resource dependence theory that educated directors tend have greater environmental awareness. Empirically, the obtained evidence provides empirical support for the findings of Gadenne et al. (2009), which indicate that there is no significant association between directors' level of education and awareness of environmental issues among Australian SMEs. Additionally, Models 2 to 4 in Table 5 indicate that LEFD is insignificantly associated with the adoption $(M C R)$ and implementation $(C N T)$ of good environmental strategies $(M C R)$, as well as disclosure about those strategies $(\mathrm{TCH})$, implying that hypotheses $3 a$, $3 b$ and $3 c$ are not empirically supported.

\section{Additional analyses}

We conduct several additional tests to check the robustness of the obtained results. For example, to control for unobserved firm-specific heterogeneity, simultaneity and dynamic endogeneity, we follow Wintoki et al. (2012) in using dynamic system GMM model. The results in Models 1 to 4 of Table 6 remain generally the same as those in Models 1 to 4 of Table 5, suggesting that our results are fairly robust to the presence of any potential problems that may arise from unobserved firm-specific heterogeneity, simultaneity or dynamic endogeneity. All the model specifications pass the AR (2) test for the second-order autocorrelation test for the validity of the instruments. In addition, to test the existence of non-linear association among board gender diversity $(B G N)$, age of female directors $(A F D)$ and firms' environmental performance (TESPR), we re-estimated Models 1 of Table 5 by adding the square of $B G N$ and AFD. Our findings in Table 6 (Models 5-8) suggest that firms' environmental performance significantly increases with the increase in the proportion of female directors. This implies that $B G N$ has non-linear relationship with firm's environmental performance. However, Models 5 to 8 in Table 6 indicate that $A F D$ has no non-linear association with firm's environmental performance.

\section{Table 6 near here}

Overall, the findings of these additional analyses make us fairly confident that our results do not appear to be driven by any potential endogenous sample selection problems.

\section{Conclusions}

Despite increasing the importance of pursing environmentally friendly activities and the significant recent changes in environment policies and regulations in China, there is a clear lack of studies (McGuinness et al., 2017) examining the extent to which corporate board gender diversity/female directors can impact on Chinese firms' environment performance. Therefore, the objective of this study is to examine the impact of female directors/corporate board gender diversity (i.e., in terms of the proportion, age and level of education of female directors) on Chinese firms' environmental performance. We interpret our findings by relying on insights from different theories (i.e., agency, legitimacy, neo-institutional, resource dependence, stakeholder, and tokenism theoretical perspectives) in order to provide better explanation of issues relating to the impact of corporate board 
diversity on firms' environmental performance. Our study, therefore, extends, as well as contributes to the existing literature in the following ways.

First, we extend the extant literature by examining the impact of board diversity on not only firms' overall environmental performance score, but also on business strategy, implementation and disclosure of environmentally friendly activities. Second, previous studies (McGuinness et al., 2017; Lau et al., 2016) examining the impact of board diversity on firm's environmental performance have focused mainly on the mere presence of female directors in the boardroom, whereas studies which have examined the impact of unique female directors' characteristics, such as their proportion, age and level of education on firm's environmental performance are scarce. Consequently, this study contributes to the extant literature by examining the impact of board gender diversity (i.e., in terms of the proportion, age and level of education of female directors) on the adoption, implementation and disclosure of environmentally responsible activities. Overall, the results indicate that board gender diversity, in the form of female directors, has a significant impact on the Chinese firms' environmental performance.

Third, our findings have important implications for regulators and policy-makers. For example, the findings suggest that environmental performance scores vary substantially among our sampled companies. This can serve as a motivation for the Chinese regulatory authorities and policy-makers to find ways to enhance the implementation and enforcement of environmental policies and laws. To promote effective compliance and enforcement of environmental policies and laws, the regulatory authorities (e.g., Shenzhen and Shanghai Stock Exchanges and China Securities Regulatory Commission) may consider establishing a special environmental compliance and enforcement committee to frequently monitor the implementation of environmental policies and laws among Chinese listed companies. Further, our findings indicate that female directors/corporate board gender diversity generally impacts positively on firm environmental performance. This implies that policy reforms that are aimed at improving the involvement of women in the top management of firms should be pursed jointly with those directed at enhancing environmental performance. In this respect, China Securities Regulatory Commission, for example, can work closely with Shenzhen and Shanghai Stock Exchanges to implement better governance and environment policies that are aimed at improving the engagement of female directors in Chinese listed companies to comply with. Additionally, our results suggest that Chinese companies with more diverse boards tend to have better environmental performance, and this may encourage Chinese policy-makers and regulators to introduce new legislations that the can serve as a motivation for Chinese companies to have diverse boards in order to improve their environmental performance. Fourth, the evidence provided in our paper provides potential insight for future studies. Our paper, for example, focused only on Chinese firms. Future research may, therefore, extend our study by including firms from both developing and developed countries.

Finally, although our results are robust across a number of econometric models, this study has some limitations, including examining environmental performance from a quantitative perspective. Similarly, like all archival research of this nature, our proxies for board gender diversity/female directors and environmental performance may or may not reflect practice. Hence, future research may offer new insights by conducting face-to-face interviews and employing case studies with directors and managers to assess the effect of board gender diversity on environmental performance. In 
addition, we relied on agency, legitimacy, stakeholder, resource dependence, neo-institutional and tokenism theories, and thus, future studies may rely on insights from other theories, such as stewardship and upper echelons theories, when examining the effect of board diversity on firm's environmental performance. Further and due to data limitations, we employed a few female directors' characteristics, such as age, proportion and education. Future studies may, therefore, offer new insights by employing other measures, such as experience, expertise and ethnicity of female directors when estimating the corporate board gender diversity-environmental performance nexus. Finally, our study focused mainly on Chinese listed firms. Future researchers may be able to extend our findings by expanding our sample to incorporate other emerging economies in Africa, Asia, Europe and Middle East, such as Brazil, Egypt, India, Indonesia, Mexico, Nigeria, Poland, Russia, South Africa, Saudi Arabia and Turkey, amongst others. 
Environmental performance - dependent variables

TESPR Is a score developed by RKS ratings agency to measure the total environmental performance.

MCR Is the first dimension of RKS scoring system and it measures the overall corporate environmental responsibility strategy.

CNT Is the second dimension of RKS scoring system and it measures effectiveness of the implemented environmental strategy.

$\mathrm{TCH}$ Is the third dimension of RKS scoring system and it measures the extent of environmental disclosure.

Board diversity - independent variables

BGN Percentage of female to total number of board members.

AFD Age of female directors.

LEFD Level of education of female directors and is defined as a continuous variable ranging from 1 to 5 (e.g., secondary school or below, junior college, undergraduate, master, and doctorate).

Controls (other corporate governance mechanisms)

BRDZ Total number of directors' on a corporate board.

SOWN 1 if the largest shareholder of a firm is a state-owned enterprise, 0 otherwise.

Controls (general firm characteristics)

FRMZ Natural logarithm of a firm total assets.

LVRG Total debt to total assets.

ROE Net profit after tax divided by total equity.

Table 1. Summary of measures and variables. 


\begin{tabular}{|c|c|c|c|c|c|c|}
\hline & All & 2011 & 2012 & 2013 & 2014 & 2015 \\
\hline \multicolumn{7}{|c|}{ Panel 1: Overall environmental performance score - TESPR (\%) } \\
\hline Mean & 38.43 & 34.06 & 35.80 & 38.12 & 40.19 & 42.26 \\
\hline Median & 35.12 & 30.39 & 32.09 & 34.15 & 36.43 & 39.55 \\
\hline STD & 13.15 & 13.23 & 13.58 & 12.54 & 12.53 & 12.50 \\
\hline Minimum & 12.53 & 12.53 & 15.12 & 18.48 & 19.70 & 18.27 \\
\hline Maximum & 87.95 & 80.29 & 81.88 & 82.44 & 87.85 & 87.18 \\
\hline \multicolumn{7}{|c|}{ Panel 2: Macrocosm score - MCR (\%) } \\
\hline Mean & 12.81 & 10.47 & 10.89 & 12.84 & 14.13 & 14.76 \\
\hline Median & 11.95 & 9.17 & 9.61 & 11.48 & 12.89 & 13.59 \\
\hline STD & 4.69 & 4.59 & 4.64 & 4.38 & 4.22 & 4.16 \\
\hline Minimum & 2.81 & 3.28 & 2.81 & 4.45 & 6.09 & 5.63 \\
\hline Maximum & 27.56 & 26.83 & 25.55 & 26.25 & 27.56 & 26.84 \\
\hline \multicolumn{7}{|c|}{ Panel 3: Content score - CNT (\%) } \\
\hline Mean & 17.22 & 15.57 & 16.44 & 17.46 & 17.84 & 18.23 \\
\hline Median & 16.17 & 14.44 & 15.56 & 16.22 & 16.70 & 17.23 \\
\hline STD & 6.02 & 5.98 & 6.36 & 5.72 & 5.72 & 6.01 \\
\hline Minimum & 3.00 & 4.88 & 3.00 & 5.63 & 6.84 & 4.10 \\
\hline Maximum & 39.59 & 35.44 & 37.13 & 37.13 & 39.59 & 38.76 \\
\hline \multicolumn{7}{|c|}{ Panel 4: Technique score - TCH (\%) } \\
\hline Mean & 6.51 & 6.40 & 6.30 & 6.12 & 6.37 & 6.86 \\
\hline Median & 5.92 & 6.03 & 5.62 & 5.29 & 5.72 & 6.22 \\
\hline STD & 1.95 & 2.56 & 1.84 & 1.85 & 1.81 & 1.65 \\
\hline Minimum & 0.56 & 0.56 & 3.31 & 4.30 & 4.14 & 4.74 \\
\hline Maximum & 17.65 & 17.65 & 16.32 & 15.88 & 14.34 & 14.47 \\
\hline
\end{tabular}

Table 2. Summary descriptive statistics of the environmental performance scores. 


\begin{tabular}{lrrrrr}
\hline Variables & Mean & Median & Std. Dev. & Min & Max \\
\hline \multicolumn{7}{l}{ Panel 1: Independent variables (board diversity) } & & & \\
BGN (\%) & 10.44 & 9.09 & 10.41 & 0.00 & 55.56 \\
AFD (years) & 51.10 & 50.00 & 7.24 & 30.00 & 73.00 \\
LEFD & 3.84 & 4.00 & 0.71 & 2.00 & 5.00 \\
& & & & \\
Panel 2: Controls (corporate governance & mechanisms) & & & \\
BRDZ (no.) & 11.19 & 11.00 & 2.92 & 5.00 & 25.00 \\
SOWN (dummy) & 0.76 & 1.00 & 0.43 & 0.00 & 1.00 \\
& & & & & \\
Panel 3: Controls (general firm characteristics) & 23.28 & 23.14 & 1.45 & 19.54 & 28.51 \\
FRMZ (lnta) & 53.50 & 54.50 & 18.66 & 5.50 & 97.17 \\
LVRG (\%) & 7.50 & 8.25 & 13.03 & -85.94 & 84.67 \\
ROE (\%)
\end{tabular}

Table 3. Summary descriptive statistics of all independent and control variables.

Please see Table 1 for variable definitions. 


\begin{tabular}{|c|c|c|c|c|c|c|c|c|c|c|c|c|}
\hline Variable & TESPR & MCR & CNT & TEC & BGN & AFD & LEFD & BRDZ & SOWN & FRMZ & LVRG & ROE \\
\hline \multicolumn{13}{|l|}{ TESPR } \\
\hline MCR & $0.94^{* * *}$ & & & & & & & & & & & \\
\hline CNT & $0.97^{* * * *}$ & $0.85^{* * *}$ & & & & & & & & & & \\
\hline $\mathrm{TCH}$ & $0.87^{* * * *}$ & $0.79^{* * *}$ & $0.81^{* * *}$ & & & & & & & & & \\
\hline BGN & $-0.05^{* *}$ & -0.03 & $-0.05^{* *}$ & -0.04 & & & & & & & & \\
\hline AFD & $0.18^{* * * *}$ & $0.16^{* * * *}$ & $0.16^{* * *}$ & $0.14^{* * * *}$ & $-0.10^{* * * *}$ & & & & & & & \\
\hline LEFD & -0.01 & -0.03 & -0.00 & -0.03 & -0.05 & $-0.18^{* * *}$ & & & & & & \\
\hline BRDZ & $0.13^{* * *}$ & $0.14^{* * * *}$ & $0.11^{* * * *}$ & $0.08^{* * * *}$ & $-0.04^{*}$ & -0.03 & 0.04 & & & & & \\
\hline SOWN & $0.16^{* * *}$ & $0.14^{* * *}$ & $0.15^{* * *}$ & $0.11^{* * *}$ & $-0.21^{* * * *}$ & $0.18^{* * * *}$ & $0.13^{* *}$ & $0.12^{* * *}$ & & & & \\
\hline FRMZ & $0.47^{* * *}$ & $0.43^{* * *}$ & $0.44^{* * *}$ & $0.42^{* * * *}$ & $-0.21^{* * * *}$ & $0.23^{* * *}$ & -0.04 & $0.16^{* * *}$ & $0.19^{* * * *}$ & & & \\
\hline LVRG & $0.08^{* * *}$ & $0.08^{* * *}$ & $0.07^{* * *}$ & $0.07^{* * *}$ & $-0.10^{* * * *}$ & $0.05^{*}$ & -0.06 & $0.041^{*}$ & $0.07^{* * * *}$ & $0.42^{* * *}$ & & \\
\hline ROE & 0.03 & 0.00 & $0.05^{*}$ & $0.07^{* * * *}$ & -0.01 & 0.03 & -0.08 & $-0.06^{* *}$ & $-0.09^{* * *}$ & $0.10^{* * * *}$ & $-0.18^{* * * *}$ & \\
\hline
\end{tabular}

Table 4. Correlation matrix.

${ }^{*}, * *$ and ${ }^{* * * *}$ represent significant at $10 \%, 5 \%$ and $1 \%$ levels, respectively.

Please see Table 1 for variable definitions. 


\begin{tabular}{|c|c|c|c|c|}
\hline $\begin{array}{l}\text { Dep. Variable } \\
\text { (Model) }\end{array}$ & $\begin{array}{l}\text { TESPR } \\
\text { (1) }\end{array}$ & $\begin{array}{l}\text { MCR } \\
(2) \\
\end{array}$ & $\begin{array}{l}\text { CNT } \\
\text { (3) }\end{array}$ & $\begin{array}{l}\mathrm{TCH} \\
(4)\end{array}$ \\
\hline \multicolumn{5}{|c|}{ Independent variables (board diversity) } \\
\hline BGN & $0.231(.005)^{* * *}$ & $0.086(.004)^{* * *}$ & $0.105(.005)^{* * *}$ & $0.032(.008)^{* * *}$ \\
\hline AFD & $0.196(.049)^{* *}$ & $0.063(.080)^{*}$ & $0.097(.033)^{* *}$ & $0.019(.085)^{*}$ \\
\hline LEFD & $0.241(.803)$ & $0.013(.969)$ & $0.146(.739)$ & $0.010(.943)$ \\
\hline \multicolumn{5}{|c|}{ Controls (corporate governance mechanisms) } \\
\hline BRDZ & $-0.197(.395)$ & $0.024(.771)$ & $-0.112(.288)$ & $-0.061(.073)^{*}$ \\
\hline SOWN & $3.197(.070)^{*}$ & $0.696(.275)$ & $1.618(.044)^{* *}$ & $0.250(.333)$ \\
\hline \multicolumn{5}{|c|}{ Controls (general firm characteristics) } \\
\hline FRMZ & $5.026(.000)^{* * *}$ & $1.570(.000)^{* * *}$ & $2.154(.000)^{* * *}$ & $0.744(.000)^{* * *}$ \\
\hline LVRG & $-0.060(.129)$ & $-0.009(.553)$ & $-0.033(.067)^{*}$ & $-0.007(.257)$ \\
\hline ROE & $-0.112(.075)^{*}$ & $-0.041(.068)^{*}$ & $-0.046(.105)$ & $-0.010(.259)$ \\
\hline Constant & $-89.098^{* * *}$ & $-28.178^{* * *}$ & $-37.973^{* * *}$ & $-11.341^{* * *}$ \\
\hline Durbin-W. Stat. & 1.864 & 1.868 & 1.847 & 1.859 \\
\hline$F$-value & $18.523^{* * *}$ & $14.520^{* * * *}$ & $16.958^{* * *}$ & $16.981^{* * *}$ \\
\hline Adj. $R^{2}$ & 0.269 & 0.222 & 0.251 & 0.252 \\
\hline No. & 1,674 & 1,674 & 1,674 & 1,674 \\
\hline
\end{tabular}

Table 5. Effects of board diversity on environmental performance.

${ }^{*},{ }^{* *}$ and ${ }^{* * * *}$ represent significant at $10 \%, 5 \%$ and $1 \%$ levels, respectively.

Please see Table 1 for variable definitions. 


\begin{tabular}{|c|c|c|c|c|c|c|c|c|}
\hline \multirow[b]{2}{*}{$\begin{array}{l}\text { Dep. Variable } \\
(\text { Model })\end{array}$} & \multicolumn{4}{|c|}{ GMM } & \multicolumn{4}{|c|}{ Non-linearity } \\
\hline & $\begin{array}{l}\text { TESPR } \\
\text { (1) }\end{array}$ & $\begin{array}{l}\text { MCR } \\
(2)\end{array}$ & $\begin{array}{l}\text { CNT } \\
(3)\end{array}$ & $\begin{array}{l}\mathrm{TCH} \\
(4)\end{array}$ & $\begin{array}{l}\text { TESPR } \\
\text { (5) }\end{array}$ & $\begin{array}{l}\text { MCR } \\
(6)\end{array}$ & $\begin{array}{l}\text { CNT } \\
(7)\end{array}$ & $\begin{array}{l}\mathrm{TCH} \\
(8)\end{array}$ \\
\hline Lagged TESPR & $0.688(.000)^{* * *}$ & $0.468(.000)^{* * *}$ & $0.515(.000)^{* * *}$ & $0.433(.000)^{* * *}$ & & & & \\
\hline \multicolumn{9}{|c|}{ Independent variables (board diversity) } \\
\hline BGN & $0.347(.002)^{* * *}$ & $0.194(.020)^{* *}$ & $0.175(.031)^{* *}$ & $0.058(.009)^{* * *}$ & $-0.697(.009)^{* * *}$ & $-0.164(.093)^{*}$ & $-0.335(.006)^{* * *}$ & $-0.079(.044)^{* *}$ \\
\hline $\mathrm{BGN}^{\mathrm{Sq}}$. & & & & & $0.021(.000)^{* * *}$ & $0.005(.008)^{* * *}$ & $0.010(.000)^{* * *}$ & $0.002(.003)^{* * *}$ \\
\hline AFD & $0.180(.515)$ & $0.240(.009)^{* * *}$ & $0.080(.593)$ & $0.320(.025)^{* *}$ & $0.656(.526)$ & $0.492(.192)$ & $0.261(.577)$ & $-0.037(.807)$ \\
\hline $\mathrm{AFD}^{\mathrm{Sq}}$ & & & & & $-0.004(.657)$ & $-0.004(.254)$ & $-0.0026(.726)$ & $0.001(.707)$ \\
\hline LEFD & $0.717(.004)^{* * *}$ & $0.049(.945)$ & $1.138(.001)^{* * *}$ & $0.337(.010)^{* *}$ & $-0.046(.962)$ & $-.106(.760)$ & $0.013(.976)$ & $-0.019(.895)$ \\
\hline \multicolumn{9}{|c|}{ Controls (corporate governance mechanisms) } \\
\hline BRDZ & $0.726(.031)^{* *}$ & $0.484(.000)^{* * *}$ & $0.144(.501)$ & $0.087(.143)$ & $-0.350(.132)$ & $-0.017(.837)$ & $-0.184(.081)^{*}$ & $-0.079(.021)^{* *}$ \\
\hline SOWN & $3.528(.206)$ & $0.719(.541)$ & $4.613(.014)^{* *}$ & $0.183(.799)$ & $3.595(.042)^{* *}$ & $0.712(.269)$ & $1.822(.023)^{* *}$ & $0.331(.204)$ \\
\hline \multicolumn{9}{|c|}{ Controls (general firm characteristics) } \\
\hline FRMZ & $2.190(.142)$ & $0.717(.175)$ & $1.296(.080)^{*}$ & $0.611(.010)^{* *}$ & $5.036(.000)^{* * *}$ & $1.590(.000)^{* * *}$ & $2.156(.000)^{* * *}$ & $0.738(.000)^{* * *}$ \\
\hline LVRG & $-0.068(.363)$ & $-0.025(.465)$ & $-0.081(.064)^{*}$ & $-0.012(.404)$ & $-0.064(.105)$ & $-0.10(.475)$ & $-0.035(.053)^{*}$ & $-0.007(.246)$ \\
\hline ROE & $-0.072(.365)$ & $-0.035(.296)$ & $-0.024(.579)$ & $-0.012(.480)$ & $-0.125(.044)^{* *}$ & $-0.046(.041)^{* *}$ & $-0.052(.063)^{*}$ & $-0.012(.205)$ \\
\hline Constant & $-62.577(.024)^{* *}$ & $-30.691(.001)^{* * *}$ & $-20.492(.160)$ & $-15.922(.000)^{* * *}$ & $-90.874^{* * *}$ & $-36.844^{* * *}$ & $-37.398^{* * *}$ & $-8.561^{* * *}$ \\
\hline$F$-value & $46.49^{* * * *}$ & $38.33^{* * *}$ & $18.24^{* * *}$ & $15.97^{* * *}$ & $16.603^{* * *}$ & $12.606^{* * *}$ & $15.474^{* * *}$ & $14.782^{* * *}$ \\
\hline Adj. $R^{2}$ & & & & & 0.291 & 0.234 & 0.276 & 0.266 \\
\hline $\mathrm{AR}(1)$ & $-3.64^{* * *}$ & $-4.09^{* * *}$ & $-3.41^{* * *}$ & $-3.21^{* * *}$ & & & & \\
\hline $\operatorname{AR}(2)$ & -0.39 & -0.04 & -0.08 & -0.17 & & & & \\
\hline No. & 857 & 857 & 857 & 857 & 1674 & 1674 & 1674 & 1674 \\
\hline
\end{tabular}

${ }^{*},{ }^{* *}$ and ${ }^{* * *}$ represent significant at $10 \%, 5 \%$ and $1 \%$ levels, respectively.

Please see Table 1 for variable definitions. 


\section{References}

Abdul Wahab, N.S., Ntim, C.G., Adnan, M.M.M., \& Ling, T.W. (2018). Top management team heterogeneity, governance changes and book-tax difference. Journal of International Accounting, Auditing and Taxation. 32, 30-46. https://doi.org/10.1016/j.intaccaudtax.2018.07.002.

Adema, W., Ali, N., Frey, V., Kim, H., Lunati, M., Piacentini, M., \& Queisser, M. (2014). Enhancing women's economic empowerment through entrepreneurship and business leadership in OECD countries. China Development Research Foundation.

Al-Bassam, W.M., Ntim, C., Opong, K.K., \& Downs, Y. (2018). Corporate boards and ownership structure as antecedents of corporate governance disclosure in Saudi Arabian publicly listed corporations. Business and Society, 57, 335-377. https://doi.org/10.1177/0007650315610611.

Alnabsha, A.M., Abdou, H., Ntim, C.G., \& Elamer, A.A. (2018). Corporate boards, ownership structures and corporate disclosures: Evidence from a developing country. Journal of Applied Accounting Research, 19(1), 20-41. https://doi.org/10.1108/JAAR-01-2016-0001.

Barako, D.G., \& Brown, A.M. (2008). Corporate social reporting and board representation: evidence from the Kenyan banking sector. Journal of Management and Governance, 12, 309-324. https://doi.org/10.1007/s10997-008-9053-X.

Bear, S., Rahman, N., \& Post, C. (2010). The impact of board diversity and gender composition on corporate social responsibility and firm reputation. Journal of Business Ethics, 97, 207-221. https://doi.org/10.1007/s10551-010-0505-2.

Ben-Amar, W., Chang, M., \& McIlkenny, P. (2017). Board gender diversity and corporate response to sustainability initiatives: evidence from the Carbon Disclosure Project. Journal of Business Ethics, 142, 369-383. https://doi.org/10.1007/s10551-015-2759-1.

Bernardi, R., Bosco, S., \& Columb, V. (2009). Does Female Representation on Boards of Directors Associate with the 'Most Ethical Companies' List? Corporate Reputation Review, 12, 270-280. https://doi.org/10.1057/crr.2009.15.

Boulouta, I. (2013). Hidden connections: The link between board gender diversity and corporate social performance. Journal of Business Ethics, 113, 185-197. https://doi.org/10.1007/s10551-0121293-7.

Branco, M.C., \& Rodrigues, L.L. (2006). Corporate social responsibility and resource-based perspectives. Journal of Business Ethics, 69, 111-132. https://doi.org/10.1007/s10551-006-9071-z

Carter, D.A., Simkins, B.J., \& Simpson, W. G. (2003). Corporate governance, board diversity, and firm value. Financial Review, 38, 33-53. https://doi.org/10.1111/1540-6288.00034.

Carter, D.A., D'Souza, F., Simkins, B.J., \& Simpson, W.G. (2010). The gender and ethnic diversity of US boards and board committees and firm financial performance. Corporate Governance: An International Review, 18, 396-414. https://doi.org/10.1111/j.1467-8683.2010.00809.x.

Carter, N., Mol, A.P. (Eds.). (2013). Environmental governance in China. Routledge.

Chen, H., Zeng, S., Lin, H., \& Ma, H. (2017). Munificence, dynamism, and complexity: How industry context drives corporate sustainability. Business Strategy and the Environment, 26, 125-141. https://doi.org/10.1002/bse.1902.

Ciocirlan, C., \& Pettersson, C. (2012). Does workforce diversity matter in the fight against climate change? An analysis of Fortune 500 companies. Corporate Social Responsibility and Environmental Management, 19, 47-62. https://doi.org/10.1002/csr.279.

Cucari, N., Esposito De Falco, S., \& Orlando, B. (2018). Diversity of Board of Directors and Environmental Social Governance: Evidence from Italian Listed Companies. Corporate Social Responsibility and Environmental Management, 25, 250-266. https://doi.org/10.1002/csr.1452.

Cummings, L. S. (2008). Managerial attitudes toward environmental management within Australia, the People's Republic of China and Indonesia. Business Strategy and the Environment, 17, 16-29. https://doi.org/10.1002/bse.515. 
Deegan, C. (2002). Introduction: The legitimising effect of social and environmental disclosures-a theoretical foundation. Accounting, Auditing and Accountability Journal, 15, 282-311. https://doi.org/10.1108/09513570210435852.

Diamantopoulos, A., Schlegelmilch, B.B., Sinkovics, R.R., \& Bohlen, G.M. (2003). Can sociodemographics still play a role in profiling green consumers? A review of the evidence and an empirical investigation. Journal of Business Research, 56, 465-480. https://doi.org/10.1016/S01482963(01)00241-7.

Dollinger, M.J. (1984). Environmental boundary spanning and information processing effects on organizational performance. Academy of Management Journal, 27, 351-368. https://www.jstor.org/stable/255929.

Du, X., Jian, W., Zeng, Q., \& Du, Y. (2014). Corporate environmental responsibility in polluting industries: Does religion matter? Journal of Business Ethics, 124, 485-507. https://doi.org/10.1007/s10551-013-1888-7.

Du, X. (2015). How the market values greenwashing? Evidence from China. Journal of Business Ethics, 128, 547-574. https://doi.org/10.1007/s10551-014-2122-y.

Elamer, A.A., Ntim, C.G., \& Abdou, H. (2018). Islamic governance, national governance and risk management and disclosures practices in MENA countries. Business \& Society. First Published: 09 December 2017. https://doi.org/10.1177/0007650317746108.

Elmagrhi, M.H., Ntim, C.G., Crossley, R., Malagila, J., Fosu, S., \& Vu, T. (2017). Corporate governance and dividend policy in UK listed SMEs: The effect of board characteristics. International Journal of Accounting and Information Management, 25(4), 459-483. https://doi.org/10.1108/IJAIM-02-2017-0020.

Elmagrhi, M.H., Ntim, C.G., Malagila, J., Fosu, S., \& Tunyi, A.A. (2018). Trustee diversity, governance mechanisms, capital structure and performance in top UK charities. Corporate Governance, 18(3), 478-508. https://doi.org/10.1108/CG-08-2017-0185.

Elmagrhi, M.H., Ntim, C.G., \& Wang, Y. (2016). Antecedents of voluntary corporate governance disclosure: A post-2007/08 financial crisis evidence from the influential UK Combined Code. Corporate Governance, 16, 507-538. https://doi.org/10.1108/CG-01-2016-0006.

Erhardt, N.L., Werbel, J.D., \& Shrader, C.B. (2003). Board of director diversity and firm financial performance. Corporate Governance: An International Review, 11, 102-111. https://doi.org/10.1111/1467-8683.00011.

Erdiaw-Kwasie, M. O., Alam, K., \& Kabir, E. (2017). Modelling corporate stakeholder orientation: does the relationship between stakeholder background characteristics and corporate social performance matter? Business Strategy and the Environment, 26, 465-479. https://doi.org/10.1002/bse.1930.

Ferrell, O.C., Fraedrich, J., \& Ferrell, L. (2017). Business ethics: ethical decision making and cases. $11^{\text {th }}$ edition. Cengage Learning. Boston. USA.

Freeman, R.E., \& Reed, D.L. (1983). Stockholders and stakeholders: A new perspective on corporate governance. California Management Review, 25, 88-106. https://doi.org/10.2307/41165018.

Gadenne, D.L., Kennedy, J., \& McKeiver, C. (2009). An empirical study of environmental awareness and practices in SMEs. Journal of Business Ethics, 84, 45-63. https://doi.org/10.1007/s10551-0089672-9.

Gao, Y. (2016). China's response to climate change issues after Paris Climate Change Conference. Advances in Climate Change Research, 7, 235-240. https://doi.org/10.1016/j.accre.2016.10.001. Gao, Y. (2009). Corporate social performance in China: Evidence from large companies. Journal of Business Ethics, 89, 23-35. https://doi.org/10.1007/s10551-008-9982-y.

Glass, C., Cook, A., \& Ingersoll, A.R. (2016). Do women leaders promote sustainability? Analysing the effect of corporate governance composition on environmental performance. Business Strategy and the Environment, 25, 495-511. https://doi.org/10.1002/bse.1879. 
Grant Thornton Report. (2018). Women in business: beyond policy to progress. Grant Thornton International Ltd.

Gujarati, D.N. (2003). Basic Econometrics, McGraw-Hill, New York, NY.

Gul, F.A., Srinidhi, B., \& Ng, A.C. (2011). Does board gender diversity improve the informativeness of stock prices? Journal of Accounting and Economics, 51, 314-338. https://doi.org/10.1016/j.jacceco.2011.01.005.

Hafsi, T., \& Turgut, G. (2013). Boardroom diversity and its effect on social performance: Conceptualization and empirical evidence. Journal of Business Ethics, 112, 463-479. https://doi.org/10.1007/s10551-012-1272-z.

Hambrick, D.C., \& Mason, P.A. (1984). Upper echelons: The organization as a reflection of its top managers. Academy of Management Review, 9, 193-206. https://www.jstor.org/stable/258434.

Haniffa, R.M., \& Cooke, T.E. (2002). Culture, corporate governance and disclosure in Malaysian corporations. Abacus, 38, 317-349. https://doi.org/10.1111/1467-6281.00112.

Haque, F., \& Ntim, C.G. (2018). Environmental policy, sustainable development, governance mechanisms and environmental performance. Business Strategy and the Environment, 27, 415-435. https://doi.org/10.1002/bse.2007.

Harjoto, M., Laksmana, I., \& Lee, R. (2015). Board diversity and corporate social responsibility. Journal of Business Ethics, 132, 641-660. https://doi.org/10.1007/s10551-014-2343-0.

He, J.K. (2015). China's INDC and non-fossil energy development. Advances in Climate Change Research, 6, 210-215. https://doi.org/10.1016/j.accre.2015.11.007.

Hitt, M.A., \& Tyler, B.B. (1991). Strategic decision models: Integrating different perspectives. Strategic Management Journal, 12, 327-351. https://www.jstor.org/stable/2486562.

Ibrahim, A.H., \& Hanefah, M.M. (2016). Board diversity and corporate social responsibility in Jordan. Journal of Financial Reporting and Accounting, 14, 279-298. https://doi.org/10.1108/JFRA-06-2015-0065.

Ibrahim, N., Angelidis, J., \& Tomic, I. 2009. Managers' Attitudes Toward Codes of Ethics: Are There Gender Differences? Journal of Business Ethics, 90, 343-353. https://www.jstor.org/stable/40665336.

Jensen, M.C., \& Meckling, W.H. (1976). Theory of the firm: Managerial behavior, agency costs and ownership structure. Journal of Financial Economics, 3, 305-360. https://doi.org/10.1016/0304405X(76)90026-X.

Jia, M., \& Zhang, Z. (2013). Critical mass of women on BODs, multiple identities, and corporate philanthropic disaster response: Evidence from privately owned Chinese firms. Journal of Business Ethics, 118, 303-317. https://doi.org/10.1007/s10551-012-1589-7.

Jia, M., \& Zhang, Z. (2011). Agency costs and corporate philanthropic disaster response: the moderating role of women on two-tier boards-evidence from People's Republic of China. International Journal of Human Resource Management, 22, 2011-2031. https://doi.org/10.1080/09585192.2011.573975.

Jiao, J., Li, J., \& Bai, Y. (2018). Ethanol as a vehicle fuel in China: A review from the perspectives of raw material resource, vehicle, and infrastructure. Journal of Cleaner Production, 180, 832-845. https://doi.org/10.1016/j.jclepro.2018.01.141.

Jizi, M. (2017). The influence of board composition on sustainable development disclosure. Business Strategy and the Environment, 26, 640-655. https://doi.org/10.1002/bse.1943.

Lau, C., Lu, Y., \& Liang, Q. (2016). Corporate social responsibility in China: A corporate governance approach. Journal of Business Ethics, 136, 73-87. https://doi.org/10.1007/s10551-014-2513-0.

Liao, L., Luo, L., \& Tang, Q. (2015). Gender diversity, board independence, environmental committee and greenhouse gas disclosure. British Accounting Review, 47, 409-424. https://doi.org/10.1016/j.bar.2014.01.002. 
Liao, L., Lin, T.P., \& Zhang, Y. (2016). Corporate board and corporate social responsibility assurance: Evidence from China. Journal of Business Ethics, 150, 1-15. https://doi.org/10.1007/s10551-016-3176-9.

Liere, K.D.V., \& Dunlap, R.E. (1980). The social bases of environmental concern: A review of hypotheses, explanations and empirical evidence. Public Opinion Quarterly, 44, 181-197. https://www.jstor.org/stable/2748427.

Li, J., Zhao, F., Chen, S., Jiang, W., Liu, T., \& Shi, S. (2017). Gender diversity on boards and firms' environmental policy. Business Strategy and the Environment, 26, 306-315. https://doi.org/10.1002/bse.1918.

McGuinness, P.B., Vieito, J.P., \& Wang, M. (2017). The role of board gender and foreign ownership in the CSR performance of Chinese listed firms. Journal of Corporate Finance, 42, 75-99. https://doi.org/10.1016/j.jcorpfin.2016.11.001.

Nasr, M. \& Ntim, C.G. (2018). Corporate governance mechanisms and accounting conservatism: Evidence from Egypt. Corporate Governance, 18(3), 386-407. https://doi.org/10.1108/CG-052017-0108.

Noronha, C., Tou, S., Cynthia, M.I., \& Guan, J.J. (2013). Corporate social responsibility reporting in China: An overview and comparison with major trends. Corporate Social Responsibility and Environmental Management, 20, 29-42. https://doi.org/10.1002/csr.1276.

Ntim, C.G. (2016). Corporate governance, corporate health accounting and firm value: The case of HIV/AIDS disclosures in Sub-Saharan Africa. International Journal of Accounting, 51(2), 155-216. https://doi.org/10.1016/j.intacc.2016.04.006.

Ntim, C.G. and Soobaroyen, T. (2013a). Corporate governance and performance in socially responsible corporations: New empirical insights from a neo-institutional framework. Corporate Governance: An International Review, 21(5), 468-494. https://doi.org/10.1111/corg.12026.

Ntim, C.G., \& Soobaroyen, T. (2013b). Black economic empowerment disclosures by South African listed corporations: The influence of ownership and board characteristics. Journal of Business Ethics, 116, 121-138. https://doi.org/10.1007/s10551-012-1446-8.

Norburn, D., \& Birley, S. (1988). The top management team and corporate performance. Strategic Management Journal, 9, 225-237. https://doi.org/10.1002/smj.4250090303.

Pfeffer, J., \& Salancik, G.R. (1978). The External Control of Organizations: A Resource Dependence Perspective, Harper and Row, New York, NY.

Post, C., Rahman, N., \& Rubow, E. (2011). Green governance: Boards of directors' composition and environmental corporate social responsibility. Business and Society, 50, 189-223. https://doi.org/10.1177/0007650310394642.

Pucheta-Martínez, M. C., \& Bel-Oms, I. (2018). What have we learnt about board gender diversity as a business strategy? The appointment of board subcommittees. Business Strategy and the Environment. First Published: 28 August 2018. https://doi.org/10.1002/bse.2226

Reverte, C. (2009). Determinants of corporate social responsibility disclosure ratings by Spanish listed firms. Journal of Business Ethics, 88, 351-366. https://doi.org/10.1007/s10551-008-9968-9.

Scott, W.R. (2001). Institutions and Organizations, 2nd ed., Sage, Thousand Oaks, CA.

Sarhan, A.A. and Ntim, C.G. (2018a). Firm- and country-level antecedents of voluntary disclosure in MENA countries. Managerial Auditing Journal. First Published: 27 July 2018. https://doi.org/10.1108/MAJ-10-2017-1688.

Sarhan, A.A., \& Ntim, C.G. (2018b). Corporate boards, shareholding structures and voluntary disclosure in emerging MENA economies. Journal of Accounting in Emerging Economies. First Published: 01 May 2018.

Shahab, Y., Ntim, C. G., Chengang, Y., Ullah, F., \& Fosu, S. (2018a). Environmental policy, environmental performance, and financial distress in China: Do top management team characteristics matter?. Business Strategy and the Environment. First Published: 03 September 2018. https://doi.org/10.1002/bse.2229. 
Shahab, Y., Ntim, C.G. and Ullah, F. (2018b). The brighter side of being socially responsible: CSR ratings and financial distress among Chinese state and non-state owned firms. Applied Economics Letters, First Published: 12 March 2018.

Soobaroyen, T. \& Ntim C.G. (2013). Social and environmental accounting as symbolic and substantive means of legitimation: The case of HIV/AIDS reporting in South Africa. Accounting Forum, 37(2), 92-109. https://doi.org/10.1016/j.accfor.2013.04.002.

Tang, M., Walsh, G., Lerner, D., Fitza, M.A., \& Li, Q. (2018). Green Innovation, Managerial Concern and Firm Performance: An Empirical Study. Business Strategy and the Environment, 27, 39-51. https://doi.org/10.1002/bse.1981.

Torchia, M,. Calabrò, A., \& Huse, M. (2011). Women directors on corporate boards: From tokenism to critical mass. Journal of Business Ethics, 102, 299-317. https://doi.org/10.1007/s10551-0110815-z.

Van Slyke, D.M. (2006). Agents or stewards: Using theory to understand the government-non-profit social service contracting relationship. Journal of Public Administration Research and Theory, 17, 157-187. https://doi.org/10.1093/jopart/mul012.

Vroom, V.H., \& Pahl, B. (1971). Relationship between age and risk taking among managers. Journal of Applied Psychology, 55, 399-405. http://dx.doi.org/10.1037/h0031776.

Wallace, R.S.O., \& Cooke, T.E. (1990). The diagnosis and resolution of emerging issues in corporate disclosure practices. Accounting and Business Research, 20: 143-151. https://doi.org/10.1080/00014788.1990.9728872.

Weber, O. (2014). Environmental, social and governance reporting in China. Business Strategy and the Environment, 23, 303-317. https://doi.org/10.1002/bse.1785.

WHO. (2014). World Health Organisation Report: 7 Million Deaths in 2014 Due to Air Pollution. WHO China.

Williams, R.J. (2003). Women on corporate boards of directors and their influence on corporate philanthropy. Journal of Business Ethics, 42, 1-10. https://doi.org/10.1023/A:1021626024014.

Wintoki, M.B., Linck, J.S., \& Netter, J.M. (2012). Endogeneity and the dynamics of internal corporate governance. Journal of Financial Economics, 105, 581-606. https://doi.org/10.1016/j.jfineco.2012.03.005.

Xu, X., Zeng, S., \& Chen, H. (2018). Signalling good by doing good: How does environmental corporate social responsibility affect international expansion? Business Strategy and the Environment. First Published: 23 February 2018. https://doi.org/10.1002/bse.2044.

Zalata, A., Ntim, C.G., Aboud, A., \& Gyapong, E. (2018). Female CEOs and core earnings quality: New evidence on the ethics versus risk-aversion puzzle. Journal of Business Ethics, First Published: 24 May 2018. https://doi.org/10.1007/s10551-018-3918-y.

Zhang, J.Q., Zhu, H., \& Ding, H.B. (2013). Board composition and corporate social responsibility: An empirical investigation in the post Sarbanes-Oxley era. Journal of Business Ethics, 114, 381392. https://doi.org/10.1007/s10551-012-1352-0.

Zimmer, L. (1988). Tokenism and women in the workplace: The limits of gender-neutral theory. Social Problems, 35, 64-77. https://www.jstor.org/stable/800667. 